\title{
SIGNIFIKASI KONTEKSTUALISASI BAHAN AJAR BAHASA ARAB BAGI PENUTUR NON ARAB
}

\author{
Ahmad Syagif Hannany Mustaufiy, M.Pd. \\ (4gyptik@gmail.com) \\ (Dosen Sekolah Tinggi Ilmu Tarbiyah Sunan Giri Bima)
}

\begin{abstract}
الملخص
اللغة العربية إحدى اللغات الأجنبية التى كثرت تعليمها في المؤسسات التروبية الرسمية وغير الرسمية بإندونليسيا. لذا، نتطلب من المعلمين والمدرسين الذين يكونون متحركين

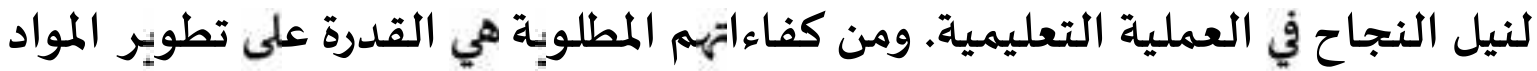
الدراسية. وكان ضعف أداء المواد التعليمية من المشكلات الأساسية في تدربس اللغة

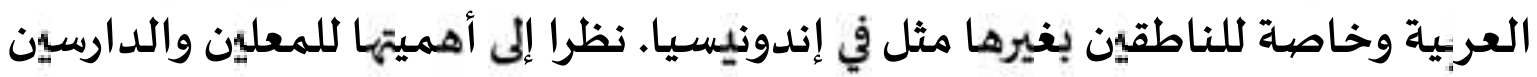

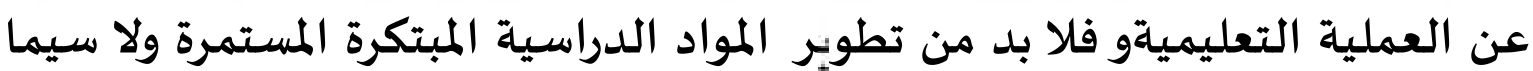
مواد اللغة العربية. ومن شروط المواد الجيدة هي السياقية. أراد هذا البحث من من خلال الدراسة المرجعية الكشف عن حقيقة المواد التعليمية وأهميتها والمشكلات المتعلقة بهاد المهيدا. ويرجى أن يكون هذا البحث المرجع الاختياري للذين يستغلون بأنشطة تطوير المواد المواد الدراسية وخاصية لتكون عناصرها ومضيمونها سياقية.
\end{abstract}

\section{كلمات المفتاح: المواد الدراسية، اللغة العريية، السياقية}

Bahasa Arab merupakan salah satu bahasa asing yang banyak diajarkan baik secara formal maupun non formal di Indonesia. Karena itu dibutuhkan figur-figur pendidik yang mampu menjadi lokomotif kesuksesan prosen pembelajaran tersebut. Salah satu kompetensi yang perlu dimiliki seorang guru dalam melaksanakan tugasnya adalah mengembangkan bahan ajar. Rendahnya kualitas bahan ajar merupakan salah satu problematika mendasar dalam pembelajaran bahasa Arab, khususnya bagi penutur non Arab seperti di Indonesia. Melihat betapa pentingnya keberadaan bahan ajar baik bagi guru maupun siswa dalam kegiatan pembelajaran, maka mutlak diperlukan pengembangan bahan ajar yang inovatif secara berkelanjutan termasuk bahan ajar bahasa Arab. Salah satu kriteria bahan ajar yang baik adalah bersifat kontekstual. Melalui studi kepustakaan, tulisan ini berusaha menggali informasi tentan konsep dan signifikansi bahan ajar dalam pembelajaran beserta problematikanya, serta kontekstualisasinya dalam pembelajaran bahasa Arab. 
Implikasikasi kajian ini diharapkan dapat menjadi referensi alternatif bagi pihak-pihak yang berkompeten dalam kegiatan pengembangan bahan ajar, khususnya dalam mengkontekstualisasikan konten dan aspek di dalamnya.

\section{Kata Kunci: Bahan Ajar, Bahasa Arab, Kontekstualisasi}

\section{A. PENDAHULUAN}

Pendidikan adalah usaha manusia (pendidik) untuk dengan penuh tanggung jawab membimbing anak didik menjadi kedewasaan. ${ }^{1}$ Pendidikan tidak hanya dipandang sebagai pemberian informasi dalam proses pembelajaran dan pembentukan keterampilan saja, namun mencakup usaha untuk mewujudkan keinginan atau citacita, kebutuhan dan kemampuan individu sehingga tercapai pola hidup pribadi dan sosial yang memuaskan dan sesuai dengan nilai-nilai yang ada di masyarakat. Salah satu aspek potensi yang harus dikembangkan dalam jiwa peserta didik adalah aspek bahasa karena anak semenjak lahir sudah mempunyai aspek bahasa dalam dirinya yang dimulai dengan masa meraba, menghafal kata, menghafal nama, mengenal benda-benda sampai pada hal yang rumit.

Bahasa merupakan bagian terpenting dalam kehidupan manusia karena dengan menggunakan bahasa, seseorang dapat berkomunikasi antara satu dengan yang lainnya. Menurut Kridalaksana ${ }^{2}$ bahasa adalah sistem lambang bunyi yang arbitrer, yang dipergunakan oleh para anggota suatu masyarakat untuk bekerja sama, berinteraksi, dan mengidentifikasikan diri. Bahasa dipelajari seseorang sejak dini sebagai sarana komunikasi dengan orang lain. Setelah seorang anak memperoleh bahasa pertamanya, maka anak itu akan mengalami proses pemerolehan bahasa kedua, melalui apa yang disebut dengan pembelajaran bahasa ${ }^{3}$. Bahasa kedua itu bisa bahasa nasional, bahasa resmi kenegaraan, bahasa resmi di kedaerahan, atau juga bahasa asing (bukan bahasa penduduk asli). ${ }^{4}$

Bahasa Arab merupakan salah satu bahasa asing yang banyak diajarkan baik secara formal maupun non formal di Indonesia. Dalam proses pembelajarannya tentu

\footnotetext{
${ }^{1}$ Fuad Ihsan, Dasar-Dasar Kependidikan Komponen MKDK, (Jakarta: Rineka Cipta, 2010), 4.

${ }^{2}$ Kridalaksana, Harimurti, Kamus Linguistik, (Jakarta: Gramedia Pustaka Utama, 1993), 21.

${ }^{3}$ Iskandarwassid, dan Dadang Sunendar, Strategi Pembelajaran Bahasa (Bandung: Remaja Rosdakarya, 2011), 77.

${ }^{4}$ Ibid., 89.
} 
membutuhkan waktu, metode pembelajaran, media pembelajaran dan sumber belajar seperti buku ajar, LKS dan lain-lain sebagaimana proses pembelajaran pada mata pelajaran lainnya. Selain itu, dibutuhkan pula figur-figur pendidik yang mampu menjadi lokomotif kesuksesan prosen pembelajaran tersebut. Mereka dituntut menjadi pendidik profesional dan berkompeten di bidangnya.

Salah satu kompetensi yang perlu dimiliki seorang guru dalam melaksanakan tugasnya adalah mengembangkan bahan ajar. Pengembangan bahan ajar penting dilakukan guru agar pembelajaran lebih efektif, efisien, dan tidak melenceng dari kompetensi yang ingin dicapai. Kompetensi mengembangkan bahan ajar idealnya telah dikuasai guru secara baik, namun pada kenyataannya masih banyak guru yang belum menguasainya, sehingga dalam melakukan proses pembelajaran masih banyak yang bersifat konvensional. Dampak dari pembelajaran konvensional ini antara lain aktivitas guru lebih dominan dan siswa kurang aktif karena lebih cenderung menjadi pendengar. Di samping itu, pembelajaran yang dilakukannya tentu kurang menarik karena pembelajaran kurang variatif. Melalui tulisan singkat ini, akan dipaparkan tentang bahan ajar; urgensinya dalam pembelajaran, serta kontekstualisasinya untuk pembelajaran bahasa Arab.

\section{B. PEMBELAJARAN BAHASA ARAB DI INDONESIA DAN PROBLEMATIKANYA BAGI PENUTUR NON ARAB}

Bahasa Arab adalah kalimat yang dipergunakan bangsa Arab dalam mengutarakan maksud dan tujuan mereka. ${ }^{5}$ Bahasa Arab sebagai alat yang terdiri dari huruf hijaiyyah yang digunakan oleh orang Arab dalam berkomunikasi dan berinteraksi sosial baik secaralisan maupun tulisan. Bahkan dikatakan bahwa bahasa Arab merupakan bahasa pertama yang digunakan Allah SWT untuk berkomunikasi dengan manusia. ${ }^{6}$ Di Indonesia Bahasa Arab merupakan salah satu bahasa asing yang diajarkan di Pesantren dan sekolah formal mulai jenjang TK, SD/MI, SMP/MTs, SMA/MA hingga Perguruan Tinggi di Indonesia agar setiap santri, peserta didik, dan mahasiswa dapat memahami ajaran Islam secara benar dan mendalam dari sumber utamanya, yaitu Al-Qur'an dan Hadis serta literatur-literatur pendukungnya yang

\footnotetext{
5 Ghalayaini, Mushthafa, Jami' ad-Durus al-'Arabiy, (Beirut: al Maktabah al 'Ashriyah, 1994), 28.

${ }^{6}$ Zulhannan, Teknik Pembelajaran Bahasa Arab Iteraktif, (Depok : Raja Grafindo Persada, 2014), 2.
} 
berbahasa Arab seperti Kitab Tafsir dan Syarah Hadis. Sehingga dengan demikian bahasa Arab menjadi kunci bagi pemahaman ajaran agama secara benar.

Seiring perkembangan zaman, bahasa Arab bukan hanya menjadi bahasa agama saja. Namun, sekarang bahasa Arab merupakan bahasa komunikasi antar manusia, sehingga tujuan pembelajaran bahasa Arab dewasa ini adalah untuk mencapai kompetensi berbahasa demi kelancaran dalam berkomunikasi menggunakan bahasa Arab. Bahkan pengguna bahasa Arab sebagaimana di tulis oleh Ahmad bin Muhammad Dibya berjumlah lebih dari 200 juta orang. Mereka menempati beberapa kawasan di Asia maupun di Afrika. Selain itu, bahasa Arab menjadi bahasa resmi internasional yang dipakai dalam forum $\mathrm{PBB}^{7}$

Sebagai sebuah mata pelajaran, bahasa Arab diajarkan untuk mendorong, membimbing, mengembangkan, dan membina kemampuan serta menumbuhkan sikap positif terhadap bahasa Arab, baik reseptif maupun produktif. Kemampuan reseptif yaitu kemampuan untuk memahami pembicaraan orang lain dan memahami bacaan. Kemampuan produktif yaitu kemampuan menggunakan bahasa sebagai alat komunikasi baik secara lisan maupun secara tertulis. Untuk itu, bahasa Arab di madrasah dipersiapkan untuk pencapaian kompetensi dasar berbahasa, yang mencakup empat keterampilan berbahasa yang diajarkan secara integral, yaitu menyimak (maharatu al istima'), berbicara (maharatu al-kalam), membaca (maharatul al Qira'ah), dan menulis (maharatu al kitabah). ${ }^{8}$ Selain itu, terdapat pula unsur-unsur kebahasaan yang diajarkan dalam pembelajaran bahasa Arab seperti tata bunyi (fonologi/'ilm alashwat), tata tulis (ortografi/kitabat al-huruf), tata kata (al-sharf), tata kalimat (nahwu), dan kosa kata (al-mufrodat). ${ }^{9}$ Dengan demikian, antara unsur-unsur dan keterampilan berbahasa tersebut tidak dapat dipisahkan satu sama lain dalam pembelajarannya.

Untuk itu, bahasa Arab di Madrasah dipersiapkan untuk pencapaian kompetensi dasar berbahasa, yang mencakup empat keterampilan berbahasa yang diajarkan secara integral, yaitu menyimak, berbicara, membaca, dan menulis. Meskipun begitu, pada tingkat pendidikan dasar (elementary) dititikberatkan pada kecakapan menyimak dan

\footnotetext{
7 Ahmad Muhtadi Anshor, Pengajaran Bahasa Arab Media dan Metode-Metodenya, (Yogyakarta: Teras, 2009), 3.

${ }^{8}$ Keputusan Direktur Jenderal Pendidikan Islam Tahun 2013.

9 Ahmad Fuad Efendy, Metodologi Pengajaran Bahasa Arab.( Malang : Misykat, 2005), 102.
} 
berbicara sebagai landasan berbahasa. Pada tingkat pendidikan menengah (intermediate), keempat kecakapan berbahasa diajarkan secara seimbang. Adapun pada tingkat pendidikan lanjut (advanced) dikonsentrasikan pada kecakapan membaca dan menulis, sehingga peserta didik diharapkan mampu mengakses berbagai referensi berbahasa Arab. ${ }^{10}$

Dalam konteks pendidikan, pelajaran bahasa Arab memiliki tujuan sebagai berikut: ${ }^{11}$

1. Mengembangkan kemampuan berkomunikasi dalam bahasa Arab, baik lisan maupun tulis, yang mencakup empat kecakapan berbahasa, yakni menyimak (istima'), berbicara (kalam), membaca (qira'ah), dan menulis (kitabah).

2. Untuk menumbuhkan kesadaran tentang hakikat sebagai salah satu bahasa asing untuk menjadi alat utama belajar, khususnya dalam mengkaji sumber- sumber ajaran Islam.

3. Mengembangkan tentang keterkaitan antara bahasa dan budaya serta memperluas cakrawala budaya. Dengan demikian peserta didik memiliki wawasan lintas budaya dan melibatkan diri dalam keragaman budaya.

Meski demikian Sampai saat ini, pembelajaran bahasa Arab di Indonesia sepertinya belum menunjukkan hasil yang memuaskan. Jika dibandingkan dengan bahasa-bahasa asing lainnya seperti bahasa Inggris, bahasa Mandarin dan bahasa Jepang, wacana pendidikan dan pengembangan bahasa Arab di Indonesia tampaknya kurang berkembang pesat, meskipun mayoritas penduduk Indonesia beragama Islam. ${ }^{12}$ Hal tersebut tidak berpengaruh banyak terhadap sikapbelajar siswa dan selanjutnya tidak pula berpengaruh terhadap hasil belajar. Guru bahasa Asing termasuk Arab, tidak bisa dibelajarkan oleh orang yang hanya bisa berbahasa Arab, itu hanya sebagian kecil saja, masih ada beberapa persyaratan kompetensi lain yang harus dimiliki seorang guru bahasa Arab yang profesional, yaitu yang terafiliasi dalam kompetensi personal, kompetensi akademik dan kompetensi paedagogik, dan kompetensi sosial.

${ }^{10}$ Departemen Agama , Standar kompetensi Standar Lulusan Dan Standar Isi PAI dan Bahasa Arab Di Madrasah, (Jakarta: Kementerian Agama, 2008), 22.

${ }^{11}$ Ibid., 23.

12 Khairi Abu Syairi, Pengembangan Bahan Ajara Bahasa Arab, (Jurnal Dinamika Ilmu Vol. 13. No.1, Juni 2013), 51 . 
Secara teoritis paling tidak ada dua problem yang sedang dan akan terus kita hadapi dalam pembelajaran bahasa Arab, khususnya bagi penutur non Arab yaitu ${ }^{13}$

1. Problem linguistik adalah persoalan-persoalan yang dihadapi siswa atau pembelajar yang terkait langsung dengan bahasa yang sedang dipelajarinya. Yaitu kesulitankesulitan yang dihadapi siswa dalam proses pembelajaran yang diakibatkan oleh karakteristik bahasa Arab itu sendiri sebagai bahasa asing bagi siswa Indonesia. Yang termasuk kedalam problem kebahasaan pengajaran bahasa adalah Problem Bunyi (Aswat Arabiyah), Problem Kosakata (Mufradat), Problem Tata Kalimat (Tarakib, Qawaid dan I'rab).

2. Problem non-Linguistik adalah persoalan-persoalan yang tidak terkait langsung dengan bahasa yang dipelajari siswa tetapi turut serta (bahkan dominan) mempengaruhi tingkat kesuksesan dan kegagalan dari pembelajaran bahasa, seperti tidk optimalnya motivasi (dawafii) dan minat (muyul) belajar, masalah perbedaaan individu siswa (furuq fardiyyah), minimnya sarana-prasarana, media dan sumber belajar (bahan ajar) bahasa Arab, terbatasnya kompetensi pendidik, metode pembelajaran yang tidak tepat dan variatif, terbatasnya alokasi waktu pembelajaran, dan lingkungan berbahasa yang tidak mendukung.

Pengetahuan serta pemahaman guru tentang berbagai problem pengajaran bahasa dianggap penting, karena dengan pemahaman itu diharapkan guru dapat meminimalisasi problem tersebut dan dapat mencari solusi yang tepat untuk mengatasinya. Sehingga apa yang diharapkan dari pembelajaran bahasa Arab dalam batas-batas minimal dapat tercapai dengan baik.

\section{BAHAN AJAR DAN SIGNIFIKANSINYA DALAM PEMBELAJARAN BAHASA ARAB.}

Berdasarkan paparan di atas, salah satu problematika pembelajaran bahasa Arab terkait dengan bahan ajar yang digunakan. Bahan ajar merupakan unsur utama dalam kurikulum disamping unsur - unsur lainnya, seperti proses, media, dan metode pembelajaran ${ }^{14}$. Bahan ajar dapat diartikan bahan-bahan atau materi pelajaran yang disusun secara lengkap dan sistematis berdasarkan prinsip-prinsip pembelajaran yang digunakan guru dan siswa dalam proses pembelajaran. Bahan ajar bersifat sistematis

13 Aziz Fakhrurrozi, Erta Mahyudin, Pembelajaran Bahasa Arab, (Jakarta: Dirjen Pendis Kemenag RI, 2012), 6-10.

14 Al-Gali, Abdullah dan Abdul Hamid Abdullah. Menyusun Buku Ajar Bahasa Arab. (Padang: Akademia Permata. 2012), IX. 
artinya disusun secara urut sehingga memudahkan siswa belajar. Di samping itu, bahan ajar juga bersifat unik dan spesifik. Unik maksudnya bahan ajar hanya digunakan untuk sasaran tertentu dan dalam proses pembelajaran tertentu, dan spesifik artinya isi bahan ajar dirancang sedemikian rupa hanya untuk mencapai kompetensi tertentu dari sasaran tertentu. ${ }^{15}$

Sementara itu menurut Gafur bahan ajar adalah pengetahuan, keterampilan dan sikap yang harus diajarkan oleh guru dan dipelajari oleh siswa. Bahan ajar tersebut berisi materi pelajaran yang harus dikuasai oleh guru dan disampaikan kepada siswa ${ }^{16}$. Sedangkan menurut Mulyasa, bahan ajar atau materi pembelajaran (instructional materials) adalah pengetahuan, keterampilan, dan sikap yang harus dipelajari siswa dalam rangka mencapai standar kompetensi yang telah ditentukan. Secara terperinci, jenis-jenis materi pembelajaran terdiri dari pengetahuan (fakta, konsep, prinsip, prosedur), keterampilan, dan sikap atau nilai. Dan menurut Soegiranto dalam Arlitasari, bahan ajar adalah bahan atau materi yang disusun oleh guru secara sistematis yang digunakan siswa di dalam pembelajaran. ${ }^{17}$

Berbagai uraian tersebut telah memberikan definisi bahan ajar, dapat disimpulkan bahwa bahan ajar yaitu segala bentuk bahan atau materi yang harus dipelajari siswa untuk mencapai suatu standar kompetensi dan kompetensi dasar yang telah ditetapkan. Adapun jenisnya, bahan ajar dibedakan menjadi empat macam, yaitu bahan cetak, bahan ajar dengar, bahan ajar pandang dengar, dan bahan ajar interaktif. ${ }^{18}$ Sementara Direktorat pembinaan SMA mengatakan bahwa jenis bahan ajar ada lima macam yaitu (1) Bahan ajar cetak, antara lain hand out, buku, modul, poster, brosur, lembar kerja siswa, wallchart, photo atau gambar, dan leaflet, (2) Bahan ajar dengar (audio), seperti kaset, radio, piringan hitam, dan compect disk audio, (3) Bahan ajar pandang dengar (audio visual) seperti compect disk video, film, (4) Bahan ajar multimedia interaktif (interactive teaching material) seperti CIA (Computer Assisted intruction), compect disk (CD), multimedia pembelajaran interaktif, dan (5) Bahan ajar berbasis web (web based learning materials). ${ }^{19}$

\footnotetext{
15 Tian Belawati, Pengembangan Bahan Ajar, (Jakarta: Pusat Penerbitan UT, 2003), 13.

16 Gafur A.. Pedoman Penyusunan Materi Pembelajaran (Instructional Material), (Jakarta: Depdiknas, 2004), 4.

17 Arlitasari, Oni dkk.. "Pengembangan Bahan Ajar IPA Terpadu Berbasis Salingtemas (Jurnal Ilmiah: Fakultas Keguruan dan Ilmu Pendidikan Universitas Negeri Sebelas Maret, 2013), 84.

${ }^{18}$ Prastowo, Andi, Panduan Kreatif Membuat Bahan Ajar Inovatif, (Jogjakarta: Diva Press, 2013), 40.

${ }^{19}$ Direktorat Pembinaan SMA Tahun 2010 Tentang Juknis Pengembangan Bahan Ajar SMA, 27.
} 
Bahan ajar dapat berperan bagi guru dan siswa. Adapun peran bahan ajar bagi guru adalah: (1) menghemat waktu guru dalam mengajar; (2) mengubah peran guru dari seorang pengajar menjadi seorang fasilitator; (3) meningkatkan proses pembelajaran menjadi lebih efektif dan interaktif. Sedangkan peran bahan ajar bagi siswa yaitu: (1) siswa dapat belajar tanpa ada guru atau teman siswa yang lainnya; (2) siswa dapat belajar kapan saja dan dimana saja ia kehendaki; (3) siswa dapat belajar menurut kecepatannya sendiri; (4) siswa dapat belajar menurut urutan yang dipilihnya sendiri; (5) membantu potensi siswa untuk belajar mandiri. Adapun dalam pembelajaran klasikal, individual dan kelompok bahan ajar berperan sebagai suplemen yang terintegrasi dengan buku utama yang memuat informasi tambahan dan relevansi antar topic untuk meningkatkan motivasi peserta didik sekaligus sebagai alat kontrolnya ${ }^{20}$

Melihat betapa pentingnya keberadaan bahan ajar baik bagi guru maupun siswa dalam kegiatan pembelajaran, maka mutlak diperlukan pengembangan bahan ajar yang inovatif secara berkelanjutan termasuk bahan ajar bahasa Arab.

\section{KONTEKSTUALISASI BAHAN AJAR BAHASA ARAB BAGI PENUTUR NON ARAB.}

Berdasarkan paparan sebelumnya mengenai posisi penting bahan ajar, seorang pendidik akan mengalami kesulitan dalam meningkatkan efektifitas pembelajaran jika tanpa disertai bahan ajar, begitu pula bagi siswa. Hal tersebut diperparah lagi, jika kapasitas pendidik dalam menjelaskan materi pembelajaran kurang cakap dan tidak mau mengembangkannya sesuai dengan konteks sosial budaya dan karakteristik peserta didik. Jika melihat pada indikator salah satu kompetensi profesional guru yang perlu dimiliki seorang guru dalam melaksanakan tugasnya adalah mengembangkan materi ajar. Pengembangan materi ajar penting dilakukan guru agar pembelajaran lebih efektif, efisien dan tidak melenceng dari kompetensi yang ingin dicapai.

Menurut Lestari ada beberapa hal yang harus diperhatikan oleh seorang pendidik dalam penyusunan bahan ajar yang mampu membuat siswa untuk belajar mandiri dan memperoleh ketuntasan dalam proses pembelajaran sebagai berikut: 1) memberikan contoh-contoh dan ilustrasi yang menarik dalam rangka mendukung pemaparan materi pembelajaran; 2) memberikan kemungkinan bagi peserta didik untuk memberikan

${ }^{20}$ Tian Belawati, et.al, Pengembangan Bahan Ajar, (Jakarta: Pusat Penerbitan UT, 2003), 14-19. 
umpan balik atau mengukur penguasaannya terhadap materi yang diberikan dengan memberikan soal-soal latihan, tugas, dan sejenisnya; 3) kontekstual, yaitu materi yang disajikan terkait dengan suasana atau konteks tugas dan lingkungan peserta didik; 4) bahasa yang digunakan cukup sederhana, karena peserta didik hanya berhadapan dengan bahan ajar ketika belajar secara mandiri. ${ }^{21}$

Dalam mengembangkan bahan ajar tersebut dapat ditempuh melalui beberapa langkah yaitu (a) Analisis dengan mengumpulkan informasi berkaitan dengan mata pelajaran dan silabusnya, juga informasi tentang karakteristik awal siswa, (b) perumusan dan perancangan hal-hal yang dikembangkan mulai dari tujuan pembelajaran, butir tes, strategi, media, dan materi, (c) penulisan dan penyusunan materi, (d) Evaluasi, review dan uji coba, serta (d) revisi. ${ }^{22}$

Melihat hal tersebut, maka perlu upaya bagi pendidik atau bahkan pihak lain yang berkompeten untuk mengkontekstualisasikan bahan ajar yang digunakan dalam pembelajaran bahasa Arab. Aspek-aspek yang perlu diperhatikan untuk menjadikan materi bahasa Arab lebih relevan dengan konteks lingkungan peserta didik adalah sebagai berikut.

1. Menyesuaikan bahan ajar, khususnya substansi dan kosa kata (mufradat) dengan konteks sosial budaya penutur. Ini perlu diupayakan karena faktanya cukup banyak lembaga pendidikan menengah hingga pendidikan tinggi yang langsung menggunakan buku ajar bahasa Arab terbitan timur tengah yang sedikit banyak pasti memiliki perbedaan dengan kultur penutur lokal seperti istilah-istilah yang berkaitan dengan penamaan benda, alat, makanan, dan lain sebagainya.

2. Mengadaptasikan konten-konten bahan ajar bahasa Arab yang memiliki kemungkinan untuk disesuaikan dengan kondisi faktual di lingkungan penutur, seperti nama orang, tempat, dan lainnya.

3. Mengembangkan bahan ajar bahasa Arab berbasis kearifan lokal sehingga peserta didik menjadi kaya pengetahuan akan budaya lokal di daerahnya sendiri. ${ }^{23}$ Dengan

\footnotetext{
${ }^{21}$ Ika Lestari. Bahan Ajar Berbasis Kompetensi, (Jakarta: Rineka Cipta, 2013), 3.

22 Abdul Hamid, dkk. Pembelajaran Bahasa Arab: Pendekatan, Metode, Strategi, Materi, dan Media, (Malang: UIN-Malang Press, 2008), 110-128.

23 Kearifan lokal adalah berupa prinsip-prinsip dan cara tertentu yang dianut, dipahami, dan di-aplikasikan oleh masyarakat lokal dalam berinteraksi dan berintere-lasi dengan lingkungannya dan diformulasikan dalam bentuk sis-tem nilai dan norma adat. Lihat Zulkarnain, Asdi Agustar, Febriyansyah, R. 2008. Kearifan Lokal Dalam Pemanfaatan Dan Pelestarian Sumberdaya Pesisir. Jurnal Agribisnis Kerakyatan. Vol 1, No. 1. (Padang:Universitas Andalas), 72. Ilmuwan antropologi, seperti Koentjaraningrat, Spradley, Taylor, dan Suparlan (dalam Fajarini 2014:124), telah mengkategorisasikan kebudayaan manusia yang menjadi wadah
} 
hal ini, maka konten-konten bahan ajar dapat memuat kebiasaan-kebiasaan setempat yang memungkinkan untuk dijadikan materi seperti makanan tradisional, permainan tradisional, tempat / artefak bersejarah atau hal lainnya yang dalam bahasa asing sering juga dikonsepsikan sebagai kebijakan setempat "local wisdom" atau pengetahuan setempat "local knowledge" atau kecerdasan setempat "local genious".

4. Mengkontekstualisasikan konten-konten yang bersentuhan dengan gender. penanaman nilai-nilai berperspektif gender sejak dini penting untuk dilakukan agar tercipta masyarakat yang berkeadilan gender, saling menghormati dan menghargai antar sesama serta merasakan kesetaraan tanpa membeda-bedakan. Dunia pendidikan merupakan ranah yang strategis untuk menanamkan nilai-nilai berpersepektif gender pada generasi muda. Sebagaimana yang diatur dalam UU tentang Sistem Pendidikan Nasional yang berbunyi: "Bahwa kesempatan pendidikan pada setiap satuan pendidikan tidakmembedakan jenis kelamin, agama, suku, ras, kedudukan sosial, dantingkat kemampuan ekonomi, dan tetap mengindahkan kekhususansatuan pendidikan yang bersangkutan". ${ }^{24} \mathrm{Hal}$ ini dapat diterapkan dalam konten-konten yang sifatnya ilustrasi atau yang memiliki hubungan dengan profesi atau pekerjaan yang melekat pada gender tertentu yang selalu digunakan secara tetap.

\section{E. PENUTUP}

Kebutuhan terhadap bahan ajar bahasa Arab sangatlah penting dalam ketercapaian tujuan pembelajaran. Seorang guru, siswa dan materi merupakan satu kesatuan yang tidak dapat dipisahkan untuk keberhasilan dalam sebuah proses pembelajaran tersebut, khususnya bagi penutur non Arab. Bahan ajar merupakan seperangkat materi atau substansi pelajaran yang disusun secara runtut dan sistematis serta menampilkan sosok utuh dari kompetensi yang akan dikuasai siswa dalam kegiatan pembelajaran. Bagi siswa, bahan ajar bisa menjadi pedoman yang akan mengarahkan semua aktivitasnya dalam proses pembelajaran, sekaligus merupakan substansi kompetensi yang seharusnya dipelajari/dikuasainya. Sedangkan bagi guru,

kearifan lokal itu kepada idea, aktivitas sosial, artefak-artefak. Lihat Fajarini, Ulfa. 2014. "Peranan Kearifan Lokal Dalam Pendidikan Karakter". Jurnal Sosio Didaktika: vol. 1, No.2. (Jakarta: Universitas Islam Negeri Syarif Hidayatullah), 124

${ }^{24}$ Lihat Pasal 7 Undang-Undang Republik Indonesia No. 20 tahun 2003 tentang Sistem Pendidikan Nasional. 
bahan ajar bisa menjadi pedoman yang akan mengarahkan semua aktivitasnya dalam proses pembelajaran, sekaligus merupakan substansi kompetensi yang seharusnya diajarkan/dilatihkan kepada siswanya.Dari sekian banyak problematika yang ada dalam proses pembelajaran bahasa Arab bagi penutur non Arab, salah satunya adalah berkaitan dengan materi ajar. Karena itulah diperlukan kesungguhan dari berbagai pihak khususnya para pendidik untuk mengembangkan bahan ajar tersebut sesuai tuntutan kebutuhan peserta didik dan perkembangan iptek. Diantara indikatornya adalah sifat kontennya yang kontekstual dengan lingkungan peserta didik yang dapat diwujudnkan dengan menyusunnya selaras dengan kondisi sosial budaya peserta didik dalam bentuk kearifan lokal maupun perspektif gender.

\section{DAFTAR PUSTAKA}

Abdul Hamid, dkk. Pembelajaran Bahasa Arab: Pendekatan, Metode, Strategi, Materi, dan Media, Malang: UIN-Malang Press, 2008.

Ahmad Fuad Efendy, Metodologi Pengajaran Bahasa Arab, Malang : Misykat, 2005.

Ahmad Muhtadi Anshor, Pengajaran Bahasa Arab Media dan Metode-Metodenya,, Yogyakarta: Teras, 2009.

Abdullah Al-Gali dan Abdul Hamid Abdullah. Menyusun Buku Ajar Bahasa Arab, Padang: Akademia Permata, 2012.

Arlitasari, Oni dkk. "Pengembangan Bahan Ajar IPA Terpadu Berbasis Salingtemas (Jurnal Ilmiah: Fakultas Keguruan dan Ilmu Pendidikan Universitas Negeri Sebelas Maret, 2013.

Andi Prastowo, Panduan Kreatif Membuat Bahan Ajar Inovatif, Jogjakarta: Diva Press, 2013.

Aziz Fakhrurrozi, Erta Mahyudin. Pembelajaran Bahasa Arab, Jakarta: Dirjen Pendis Kemenag RI, 2012.

Departemen Agama, Standar Kompetensi Standar Lulusan Dan Standar Isi PAI dan Bahasa Arab Di Madrasah, (Jakarta:T.P, ), 2008.

Direktorat Pembinaan SMA Tahun 2010 Tentang Juknis Pengembangan Bahan Ajar SMA.

Ulfa Fajarini, "Peranan Kearifan Lokal Dalam Pendidikan Karakter". Jurnal Sosio Didaktika: vol. 1, No.2. Jakarta: Universitas Islam Negeri Syarif Hidayatullah, 2014.

Fuad Ihsan, 2010, Dasar-Dasar Kependidikan Komponen MKDK, (Jakarta: Rineka Cipta) 
Gafur A. Pedoman Penyusunan Materi Pembelajaran (Instructional Material, Jakarta: Depdiknas, 2004.

Ika Lestari, Bahan Ajar Berbasis Kompetensi, Jakarta: Rineka Cipta, 2013.

Iskandarwassid, dan Dadang Sunendar, Strategi Pembelajaran Bahasa, Bandung: Remaja Rosdakarya, 2011.

Keputusan Direktur Jenderal Pendidikan Islam Tahun 2013

Khairi Abu Syairi, Pengembangan Bahan Ajara Bahasa Arab, Jurnal Dinamika Ilmu Vol. 13. No.1, Juni 2013.

Harimurti Kridalaksana, Kamus Linguistik, Jakarta: Gramedia Pustaka Utama, 1993.

Mustafa Ghalayaini. Jami' ad-Durus al- 'Arabiy, Beirut: al Maktabah al 'ashriyah, 1994.

Tian Belawati, Pengembangan Bahan Ajar, Jakarta: Pusat Penerbitan UT, 2003.

Undang-Undang Republik Indonesia No. 20 tahun 2003 tentang Sistem Pendidikan Nasional.

Zulhannan, Teknik Pembelajaran Bahasa Arab Iteraktif, Depok: Raja Grafindo Persada, 2014.

Zulkarnain dkk. Kearifan Lokal Dalam Pemanfaatan Dan Pelestarian Sumberdaya Pesisir. Jurnal Agribisnis Kerakyatan. Vol 1, No. 1. (Padang:Universitas Andalas), 2008. 